\title{
Louisa Catherine
}


This page intentionally left blank 


\section{LOUISA}

\section{Catherine}

The Other Mrs. Adams

\section{Margery M. Heffron}

Edited by David L. Michelmore

\section{Yale \\ UNIVERSITY \\ PRESS}

New Haven \& London 
Published with assistance from the Annie Burr Lewis Fund and the Mary Cady Tew Memorial Fund.

Copyright (C) 2014 by The Estate of Margery Heffron. All rights reserved.

This book may not be reproduced, in whole or in part, including illustrations, in any form (beyond that copying permitted by Sections 107 and 108 of the U.S. Copyright Law and except by reviewers for the public press), without written permission from the publishers.

Yale University Press books may be purchased in quantity for educational, business, or promotional use. For information, please e-mailsales.press@yale.edu (U.S. office) or sales@yaleup.co.uk (U.K. office).

Set in Electra type by IDS Infotech Ltd., Chandigarh, India. Printed in the United States of America.

Library of Congress Cataloging-in-Publication Data

Heffron, Margery M., 1939-2011.

Louisa Catherine : the other Mrs. Adams / Margery M. Heffron ; edited by David L. Michelmore. pages $\mathrm{cm}$

Includes bibliographical references and index.

ISBN 978-0-300-19796-9 (cloth : alk. paper) 1. Adams, Louisa Catherine, $1775^{-1852}$. 2. Presidents' spouses - United StatesBiography. 3. Adams, John Quincy, 1767-1848. I. Michelmore, David L., 1947- editor. II. Title.

$$
\begin{gathered}
\mathrm{E}_{377 \cdot 2 . \mathrm{H}_{44} 2 \mathrm{O} 4} \\
973.5{ }^{\prime} 5092-\mathrm{dc}_{23} \quad[\mathrm{~B}] \quad 2013042868
\end{gathered}
$$

A catalogue record for this book is available from the British Library.

This paper meets the requirements of ANSI/NISO Z39.48-1992 (Permanence of Paper). 